Ariyanti, M. S. Rosniawaty $\cdot$ H.A. Utami

\title{
Pertumbuhan bibit kelapa sawit (Elaeis guineensis Jacq.) dengan pemberian kompos blotong disertai dengan frekuensi penyiraman yang berbeda di pembibitan utama
}

\section{The growth response of oil palm (Elaeis guineensis Jacq.) toward the application of several dosage of filter cake compost accompanied with the different interval time of watering in main nursey}

Diterima : 24 Oktober 2018/Disetujui : 10 Desember 2018 / Dipublikasikan : 31 Desember 2018

CDepartment of Crop Science, Padjadjaran University

\begin{abstract}
Filter cake is one form of the sugar mill waste, however it has an beneficial value as organic fertilizer. Filter cake of canes contains some plant nutrients such as $1.51 \% \mathrm{~N}, 5.63 \%$ $\mathrm{P} 2 \mathrm{O} 5, \quad 0.26 \% \quad \mathrm{~K}_{2} \mathrm{O}$ and $32.38 \%$ C-organic elements. The use of filter cake as organic fertilizer is expected to be reduce the use of inorganic fertilizers where excessive usage over a long period that caused the degradation of soil quality if without organic in application. The purpose of this experiment is was to examine the growth of oil palm seedlings by giving filter cakes compost combined with different watering frequencies. The experiment was conducted from December 2017 to April 2018 at the Ciparanje Experimental station, Faculty of Agriculture, Padjadjaran University. A randomized block design (RBD) was used as the experimental design with four levels of fertilizer (without filter cakes (inorganic), 500, 1000, and $1500 \mathrm{~g}$ filter cake per plant) and the frequency of watering (every day, every 3 days, and every 5 days). The results of the experiment showed that filter cake compost of $1500 \mathrm{~g} /$ plant and watering of every day was the best result on growth of oil palm seedlings, particularly on the parameters of plant height, circumstance stems, number of leaves and fresh weight of plants. Filter cakes compost in this study contains $32.38 \%$ C-organic, $1.51 \% \mathrm{~N}, 5.63 \% \mathrm{P}_{2} \mathrm{O}_{5}$, and $0.26 \% \mathrm{~K}_{2} \mathrm{O}$.
\end{abstract}

Keywords: Oil palm • Main nursery $\cdot$ Filter cake $\cdot$ Watering frequency

Dikomunikasikan oleh Mochamad Arief Soleh

Ariyanti, M.1.S. Rosniawaty ${ }^{1}$. H.A. Utami ${ }^{1}$

Departemen Budidaya Pertanian, Fakultas Pertanian,

Universitas Padjadjaran.

Korespondensi : mira. ariyanti@unpad.ac.id
Sari. Blotong merupakan salah satu bentuk limbah di pabrik gula yang memiliki nilai manfaat untuk diterapkan sebagai pupuk organik. Pada blotong terkandung beberapa unsur hara yang bermanfaat bagi tanaman yaitu unsur $1.51 \% \mathrm{~N}, 5.63 \% \mathrm{P}_{2} \mathrm{O}_{5}$, $0.26 \% \mathrm{~K}_{2} \mathrm{O}$ dan $32.38 \%$ C-organik. Selain itu pemanfaatan blotong sebagai pupuk organik diharapkan mengurangi penggunaan pupuk anorganik dimana penggunaan yang berlebihan dalam jangka waktu yang lama secara terus menerus akan menyebabkan tanah tidak sehat karena mengerasnya lapisan tanah. Tujuan percobaan ini adalah mengkaji pertumbuhan bibit kelapa sawit dengan pemberian kompos blotong yang dikombinasikan dengan frekuensi penyiraman yang berbeda. Percobaan dilakukan mulai Desember 2017 sampai dengan April 2018 di Kebun Percobaan Ciparanje, Fakultas Pertanian Universitas Padjadjaran. Percobaan menggunakan rancangan acak kelompok (RAK) dengan perlakuan pemberian pupuk (pupuk anorganik, kompos blotong $500 \mathrm{~g} /$ tanaman, kompos blotong dosis $1000 \mathrm{~g} /$ tanaman, kompos blotong $1500 \mathrm{~g} /$ tanaman) dan frekuensi penyiraman (setiap hari, 3 hari sekali, dan 5 hari sekali). Hasil percobaan menunjukkan bahwa pemupukan dengan kompos blotong $1500 \mathrm{~g} /$ tanaman yang disertai dengan penyiraman setiap hari menghasilkan pertumbuhan terbaik bibit kelapa sawit terutama pada parameter tinggi tanaman, lilit batang, jumlah daun dan bobot basah tanaman. Kompos blotong mengandung $32.38 \%$ C-organik, $1.51 \% \mathrm{~N}, 5.63 \%$ $\mathrm{P}_{2} \mathrm{O}_{5}$, dan $0.26 \% \mathrm{~K}_{2} \mathrm{O}$.

Kata kunci: Kelapa sawit • Pembibitan utama • Blotong · Frekuensi penyiraman 


\section{Pendahuluan}

Kelapa sawit (Elaeis guineensis Jacq.) merupakan salah satu komoditas tanaman perkebunan yang sangat penting untuk terus dikembangkan di Indonesia. Total areal perkebunan kelapa sawit di Indonesia sampai dengan tahun 2017 adalah 12.307.677 ha, total produksi sebesar 35.359.384 ton dengan volume dan nilai total produksi berturut-turut sebesar 1.126.194 ton, 1.276.098.000 USD pada tahun 2016 (Direktorat Jenderal Perkebunan, 2017). Permintaan minyak kelapa sawit yang semakin meningkat menurut laporan World Growth (2011) memicu produksi minyak sawit dunia diperkirakan meningkat 32 persen menjadi hampir 60 juta ton menjelang 2020. Hal ini menuntut Indonesia untuk mampu meningkatkan kualitas dan kuantitas kelapa sawit itu sendiri.

Bibit kelapa sawit berkualitas tidak hanya berasal dari benih unggul tetapi faktor teknik budidaya lainnya ikut berperan penting diantaranya pemupukan dan pengairan. Pada saat pembibitan seringkali ketersediaan air untuk penyiraman menjadi kendala sehingga apabila hal tersebut terjadi bibit kerap mengalami kekeringan sehingga akan berpengaruh terhadap pertumbuhan bibit selanjutnya. Setiap bibit kelapa sawit membutuhkan air ratarata 2,25 liter atau setara dengan curah hujan efektif 3,4 mm/hari (Allorerung dkk, 2010). Menurut Lubis (2008), kebutuhan air untuk bibit sawit pada pembibitan utama berkisar antara 1 3 liter/bibit/hari. Penyiraman tidak perlu dilakukan apabila turun hujan dalam jumlah memadai (minimal $6-8 \mathrm{~mm} /$ hari) (Allorerung dkk, 2010).

Kebutuhan air bagi tanaman mutlak harus dipenuhi sehingga perlu dilakukan usaha agar tanaman tetap dapat memenuhi kebutuhan airnya meskipun ketersediaan air bagi penyiraman kurang atau bahkan tidak tersedia secara terus menerus. Media tanam yang digunakan dalam pembibitan diusahakan dapat menyimpan air lebih lama untuk tanaman melalui penambahan pupuk organik yang berperan dalam meningkatkan kapasitas memegang air tanah. Selain itu penambahan pupuk organik pada media tanam juga berkontribusi dalam menyediakan unsur hara yang dibutuhkan tanaman. Pupuk organik dapat dibuat dengan memanfaatkan limbah perkebunan baik yang berasal dari perkebunan itu sendiri atau dari perkebunan lainnya. Limbah perkebunan yang banyak dimanfaatkaan sebagai bahan pupuk organik diantaranya blotong, tandan kosong kelapa sawit, pelepah kelapa sawit, kulit buah kopi, kulit tanduk kopi, ampas teh, tatal karet.

Salah satu limbah perkebunan yang dimanfaatkan sebagai bahan pupuk organik adalah blotong yang merupakan limbah proses produksi gula Pemanfaatan blotong sebagai pupuk organik diharapkan mampu mengurangi penggunaan pupuk anorganik dan mengurangi dampak pencemaran lingkungan. Blotong yang langsung diberikan pada pertanaman akan menganggu pertumbuhan tanaman karena blotong segar masih mengandung $\mathrm{C} / \mathrm{N}$ yang tinggi, untuk itu blotong harus dikomposkan terlebih dahulu (Astuti dkk, 2015). Blotong cocok untuk dijadikan pupuk organik karena memiliki kandungan unsur hara sebesar Corganik 32,28\%, C/N 21,44, pH 8,03, N-total 1,51\%, P-total 5,63\%, dan K-total 0,26\% (Hasil analisis di Laboratorium Kimia Tanah dan Nutrisi Tanaman, Universitas Padjajaran, 2018).

Kompos blotong sebagai pupuk organik mampu memperbaiki sifat fisik tanah di areal perkebunan tebu seperti menurunkan laju pencucian hara, memperbaiki drainase tanah, menetralisir unsur alumunium yang mengikat $P$ sehingga ketersediaan $\mathrm{P}$ dalam tanah lebih tersedia, dan meningkatkan kapasitas menahan air (Kirana, 2008). Kemampuan blotong mampu menahan air dibuktikan dengan penelitian Purwono dkk (2011) bahwa pemberian air dapat dikurangi dari seminggu sekali menjadi 2 minggu sekali pada pertanaman tebu dengan pemberian pupuk kompos blotong sebanyak 5 ton per hektar.

Bibit kelapa sawit memerlukan air yang cukup untuk pertumbuhannya terutama untuk tanaman yang masih muda (Zaenal, 2010). Kebutuhan air kelapa sawit didapatkan dari nilai evapotranspirasi (Baskoro, 2017). Menurut Coster dalam Gapki (2017), sawit memiliki nilai evapotranspirasi sebesar $1.104 \mathrm{~mm} /$ tahun atau $3.03 \mathrm{~mm} /$ hari. Ketersediaan air dalam tanah dapat dikelola dengan baik melalui kegiatan penyiraman. Frekuensi penyiraman yang terlalu panjang akan menimbulkan kekeringan, sedangkan penyiraman yang terlalu sering atau berlebihan akan mengakibatkan pemadatan tanah (Ichsan dkk., 2012)

Bibit kelapa sawit yang mengalami cekaman air dicirikan dengan daun tombak 
tidak membuka, daun muda mengering, klorosis, dan mempercepat kematian tanaman (Pangaribuan, 2001). Kompos blotong diharapkan mampu memperpanjang frekuensi penyiraman yang bertujuan menghemat penggunaan air di pembibitan kelapa sawit.

Tujuan penelitian ini adalah mengkaji pertumbuhan bibit kelapa sawit dengan pemberian kompos blotong yang disertai dengan frekuensi penyiraman yang berbeda.

\section{Bahan dan Metode}

Percobaan dilaksanakan pada bulan Desember 2017 sampai bulan April 2018 di kebun percobaan Ciparanje, Jatinangor, Fakultas Pertanian, Universitas Padjadjaran dengan ketinggian \pm 752 meter di atas permukaan laut (mdpl) dengan curah hujan bertipe C (agak basah) menurut klasifikasi Schmidt dan Fergusson (1951).

Bahan yang digunakan yaitu kelapa sawit jenis Tenera varietas Simalungun berumur 6 bulan yang diperoleh dari Pusat Penelitian Kelapa Sawit (PPKS) Medan yang dikembangkan di Palembang, polybag besar ukuran $(40 \times 30) \mathrm{cm}$, NPK majemuk tablet Suburin $(15: 15: 6,5)$ yang telah dihancurkan, tanah topsoil ordo Inseptisol dan blotong tebu yang berasal dari PT PG Rajawali II unit Subang. Alat yang digunakan dalam penelitian ini berupa alat kadar air Gardsens, Klorofilmeter, gelas ukur, meteran, timbangan analitik, kamera, pisau, plastik, amplop dan oven.

Rancangan percobaan yang digunakan adalah Rancangan Acak Kelompok (RAK). Terdapat 12 perlakuan, masing-masing perlakuan diulang 3 kali dan tiap ulangan terdiri dari 2 bibit sehingga jumlah bibit yang diperlukan adalah 72 bibit. Perlakuan terdiri dari pupuk anorganik (dosis pupuk yang diberikan sesuai kebutuhan tanaman berdasarkan umur tanaman), kompos blotong $500 \mathrm{~g} /$ tanaman, kompos blotong $1000 \mathrm{~g} /$ tanaman, kompos blotong $1500 \mathrm{~g} /$ tanaman dan frekuensi penyiraman setiap hari, tiga hari sekali, dan lima hari sekali. Pada setiap perlakuan kompos blotong ditambahkan pupuk anorganik sebanyak 30\% dari dosis anorganik anjuran. Pupuk anorganik NPK dosis anjuran untuk setiap tanaman disesuaikan dengan kebutuhan tanaman berdasarkan umur yaitu pada 1 BSP (umur tanaman 6 bulan) sebanyak $7 \mathrm{~g}$, pada 2
BSP (umur tanaman 7 bulan) sebanyak $10 \mathrm{~g}$, pada 3 BSP (umur tanaman 7 bulan) sebanyak 20 g, pada 4 BSP (umur tanaman 8 bulan) sebanyak $25 \mathrm{~g}$.

Analisis ragam menggunakan uji $\mathrm{F}$ pada taraf 5\% dan uji lanjut berganda Duncan pada taraf 5\% dilakukan apabila terdapat perbedaan diantara perlakuan.

\section{Hasil dan Pembahasan}

Hasil analisis tanah yang digunakan sebagai media tanam adalah memiliki $\mathrm{pH}$ agak masam (5.77), C-organik sedang (2.59\%), $\mathrm{N}$ total sedang $(0.26 \%), \mathrm{C} / \mathrm{N}$ rendah (10), $\mathrm{P}_{2} \mathrm{O}_{5}$ sangat tinggi (23.68 ppm), $\mathrm{K}_{2} \mathrm{O}$ tinggi $(43.34 \mathrm{mg} / 100 \mathrm{~g})$ dan tergolong tanah ordo Inceptisol.

Berdasarkan hasil analisis, kompos blotong mengandung $32.38 \%$ C-organik, $1.51 \% \mathrm{~N}, 5.63 \%$ $\mathrm{P}_{2} \mathrm{O}_{5}$, dan $0.26 \% \quad \mathrm{~K}_{2} \mathrm{O}, \mathrm{C} / \mathrm{N}$ 21.44, $\mathrm{pH} 8.3$ sedangkan pupuk anorganik mengandung $15 \%$ $\mathrm{N}, 15 \% \mathrm{P}_{2} \mathrm{O}_{5}, 6.5 \% \mathrm{~K}_{2} \mathrm{O}$.

Pertumbuhan Vegetatif. Pemberian kompos blotong berbeda dosis yang disertai dengan frekuensi penyiraman yang berbeda menghasilkan respons yang berbeda pada rerata pertambahan tinggi tanaman dan rerata pertambahan lilit batang (Gambar 1), rerata luas daun dan rerata jumlah daun (Gambar 2) dan rerata bobot basah tanaman dan rerata bobot kering tanaman (Gambar 3). Pemberian kompos blotong dengan dosis $1500 \mathrm{~g} /$ tanaman yang disertai dengan penyiraman setiap hari menghasilkan pertumbuhan bibit kelapa sawit tertinggi yaitu $5.57 \mathrm{~cm}$ pada 4 BSP (bulan setelah perlakuan). Pertumbuhan tinggi tanaman yang diberi kompos blotong $1500 \mathrm{~g} /$ tanaman ternyata lebih baik dibandingkan tanaman yang diberi pupuk anorganik dengan frekuensi penyiraman yang sama yaitu setiap hari (Gambar 1a). Disamping itu kandungan $\mathrm{N}$ yang lebih tinggi pada kompos blotong yaitu sekitar $0.15 \%$ sehingga pada 1500 g kompos blotong terkandung sebanyak $22.5 \mathrm{~g}$ $\mathrm{N}$ dapat memicu pertumbuhan tanaman lebih tinggi dibandingkan pupuk anorganik yang hanya mendistribusikan sekitar $9.3 \mathrm{~g} \mathrm{~N}$ pada tanaman kelapa sawit. Pupuk anorganik (dosis anjuran 100\%) dapat digantikan dengan dengan pupuk kompos blotong mulai dosis 1500 $\mathrm{g} /$ tanaman. Menurut Mulyadi (2000), pemberian blotong mampu meningkatkan tinggi tanaman, diameter batang, dan bobot kering tebu bagian atas berumur 4 bulan. 


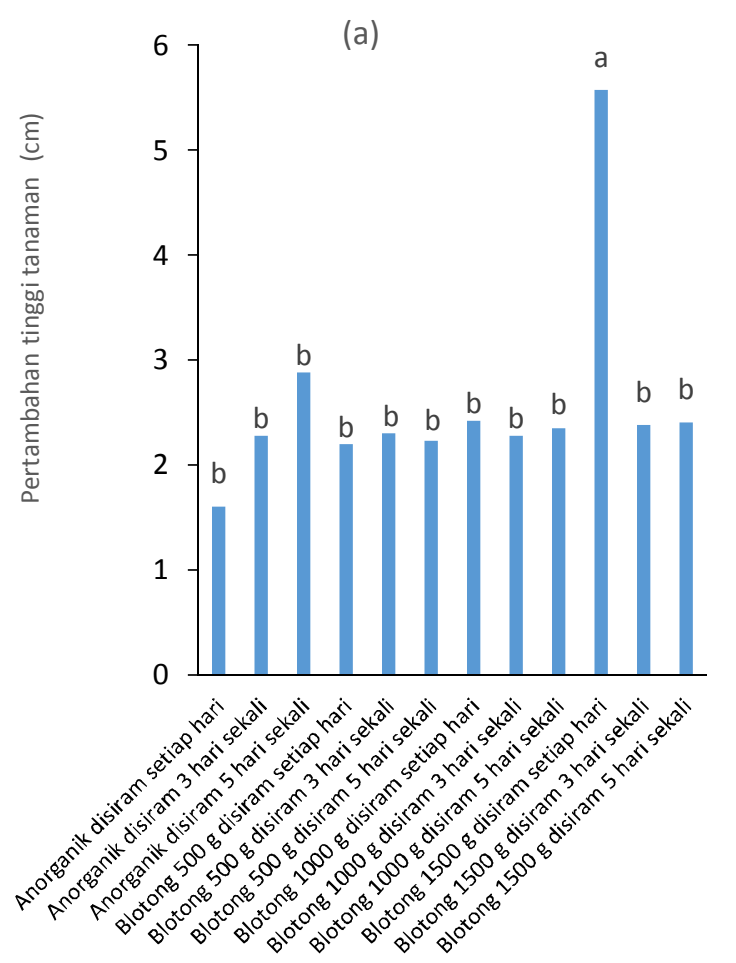

(b)

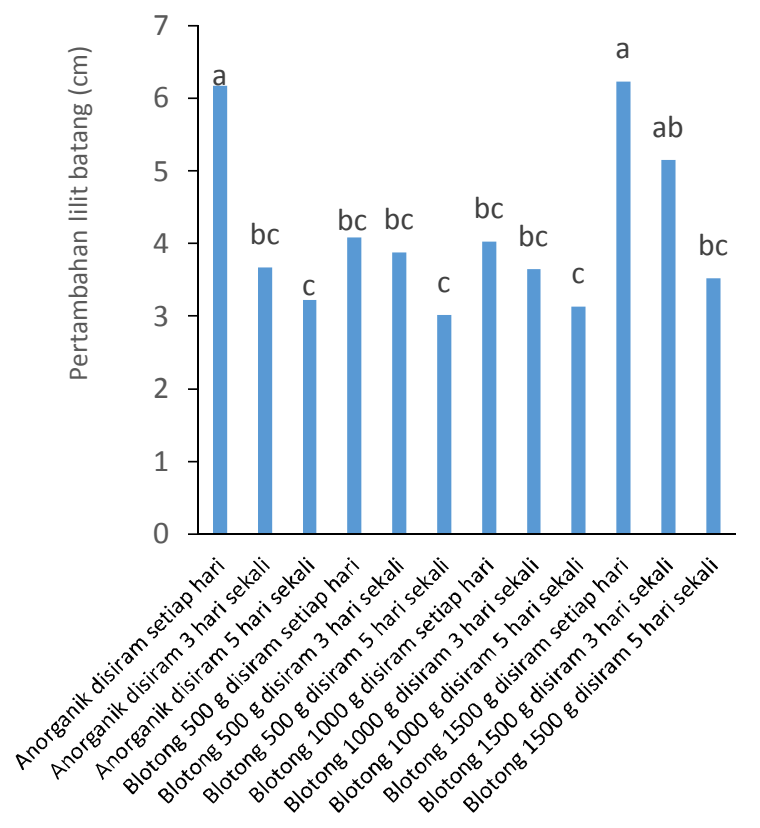

Gambar 1. Diagram rerata pertambahan tinggi (a) dan rerata pertambahan lilit batang (b) bibit kelapa sawit dengan pemberian kompos blotong tebu dengan frekuensi penyiraman yang berbeda pada 4 BSP.

Pemberian kompos disertai penyiraman yang tepat akan menghasilkan pertumbuhan tinggi tanaman yang baik. Menurut Ariyanti dkk (2018a), komposisi media tanam subsoil dan kompos (1:3) disertai penyiraman 2 hari sekali menghasilkan pertumbuhan bibit kelapa sawit yang terbaik terutama pengaruhnya terhadap pertambahan tinggi tanaman, pertambahan lilit batang dan bobot kering tajuk.

Nilai C/N kompos blotong sebesar 21.44 tampaknya menciptakan kondisi yang memungkinkan dalam meningkatkan ketersediaan $\mathrm{N}$ (nitrogen) dalam tanah (Yassen dkk, 2010). Kandungan $\mathrm{N}$ pada kompos memberikan pengaruh yang baik bagi pertumbuhan bibit kelapa sawit. Nitrogen merupakan komponen penyusun berbagai senyawa essensial seperti asam amino (Lakitan, 2010). Unsur ini berperan dalam pembelahan dan perpanjangan sel sehingga mempengaruhi pertumbuhan tinggi tanaman (Gunawan dkk, 2014).

Pada 4 BSP perlakuan pemberian pupuk anorganik yang disertai penyiraman setiap hari menghasilkan pertumbuhan lilit batang yang tidak berbeda nyata dengan perlakuan pemberian kompos blotong $1500 \mathrm{~g} /$ tanaman dengan penyiraman setiap hari dan tiga hari sekali, namun berbeda nyata dengan perlakuan pupuk anorganik, kompos blotong $500 \mathrm{~g} /$ tanaman dan $1000 \mathrm{~g} /$ tanaman yang masing-masing disertai dengan penyiraman lima hari sekali (Gambar 1b). Perlakuan kompos blotong $1500 \mathrm{~g} /$ tanaman disertai penyiraman setiap hari menghasilkan lilit batang terbesar dan tidak berbeda nyata dengan perlakuan penyiraman 3 hari sekali disertai pemberian kompos blotong dengan dosis yang sama (Gambar 1b). Hal ini menunjukkan bahwa pemberian kompos $1500 \mathrm{~g} /$ tanaman dengan frekuensi penyiraman yang lebih panjang yaitu 3 hari sekali dapat menghasilkan bibit dengan pertumbuhan lilit batang yang sama baik dengan penyiraman yang dilakukan setiap hari.

Sejalan dengan penelitian Ariyanti dkk (2018b) yang menyatakan bahwa pemberian kompos tandan kosong kelapa sawit yang disertai dengan penyiraman 1,5 - 2,5 liter per polybag setiap 3 hari sekali menghasilkan lilit batang dan jumlah daun bibit kelapa sawit yang terbaik. Hal ini diduga unsur $\mathrm{P}$ yang terkandung di dalam kompos blotong dosis tertinggi telah mampu berperan baik dalam penyusunan inti sel dalam pembelahan sel, dan pengembangan jaringan meristem (Satari dkk, 2009). Unsur N yang terkandung dalam kompos blotong ikut 
berkontribusi dalam peningkatan pertumbuhan batang kelapa sawit (Gunawan dkk, 2014).

Perlakuan kompos blotong $1500 \mathrm{~g} /$ polybag disertai penyiraman tiga hari sekali lebih efisien diaplikasikan karena dapat menghemat air lebih dari $67 \%$ penggunaan air dapat dikurangi namun tetap memberikan hasil yang baik. Penghematan air sebanyak $67 \%$ diperoleh dengan asumsi bahwa apabila air yang diperlukan untuk penyiraman setiap hari adalah 6 liter dengan penggunaan 21 setiap hari sedangkan penyiraman 3 hari sekali membutuhkan 2 liter air saja. Pengurangan air sebanyak 4 liter merupakan penghematan air yang digunakan

(a)

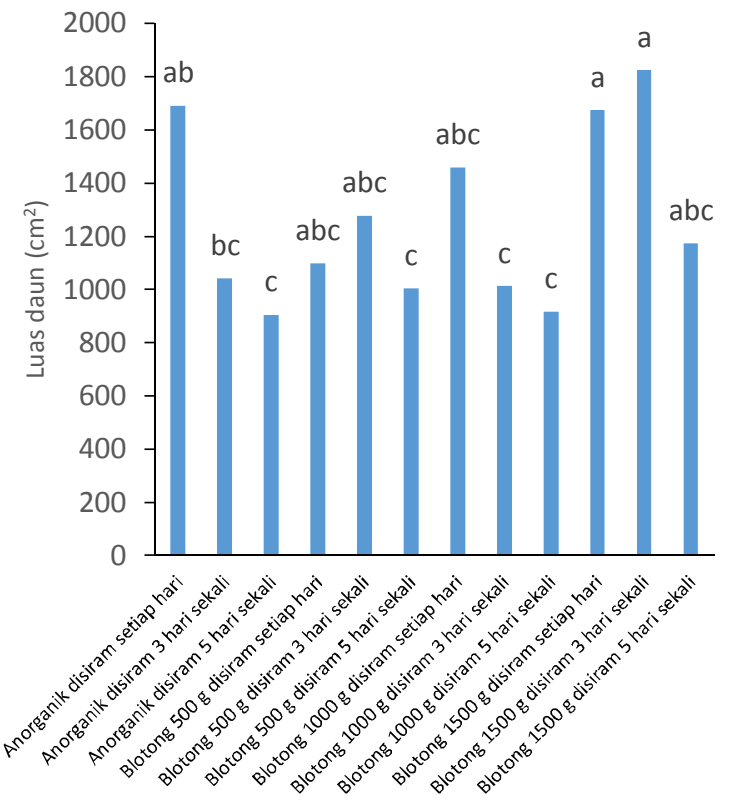

dengan 6 liter sebagai pembanding sehingga diperoleh angka persentase bernilai $67 \%$. Menurut Purwono (2011), kompos blotong memiliki ukuran molekul kecil seperti molekul mineral liat namun memiliki kemampuan mengikat dan melepaskan air dengan baik. Perlakuan pupuk anorganik rekomendasi, kompos blotong $500 \mathrm{~g} /$ tanaman dan 1000 $\mathrm{g} /$ tanaman yang ketiganya dikombinasikan dengan penyiraman lima hari sekali menghasilkan pertumbuhan tanaman yang relatif rendah. Hal ini diduga kekurangan air mempengaruhi turgor sel sehingga penyerapan hara dan pembelahan sel terhambat (Maryani, 2012).

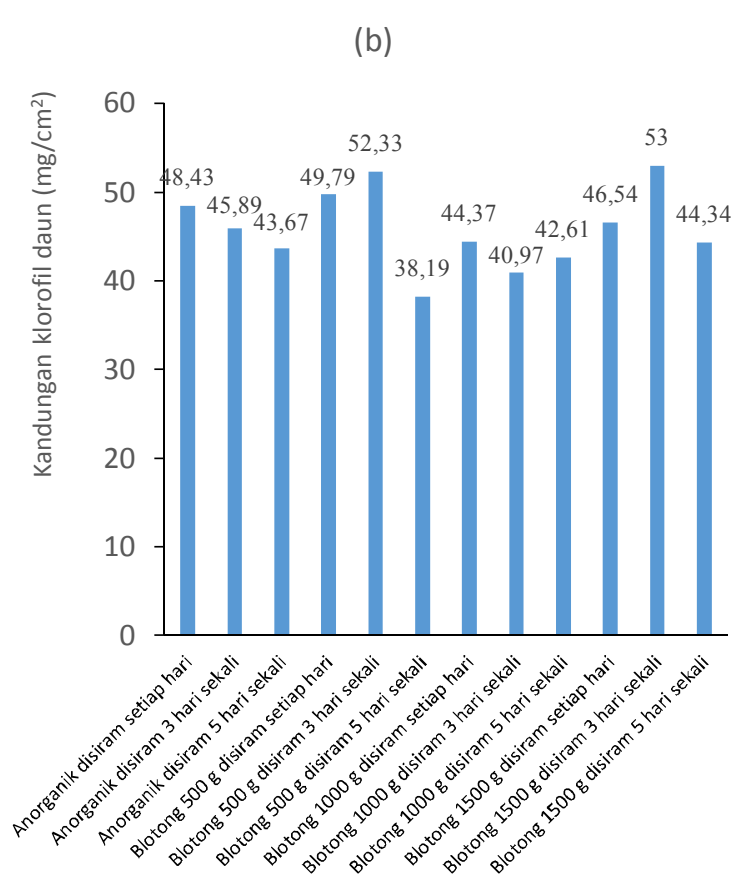

(c)

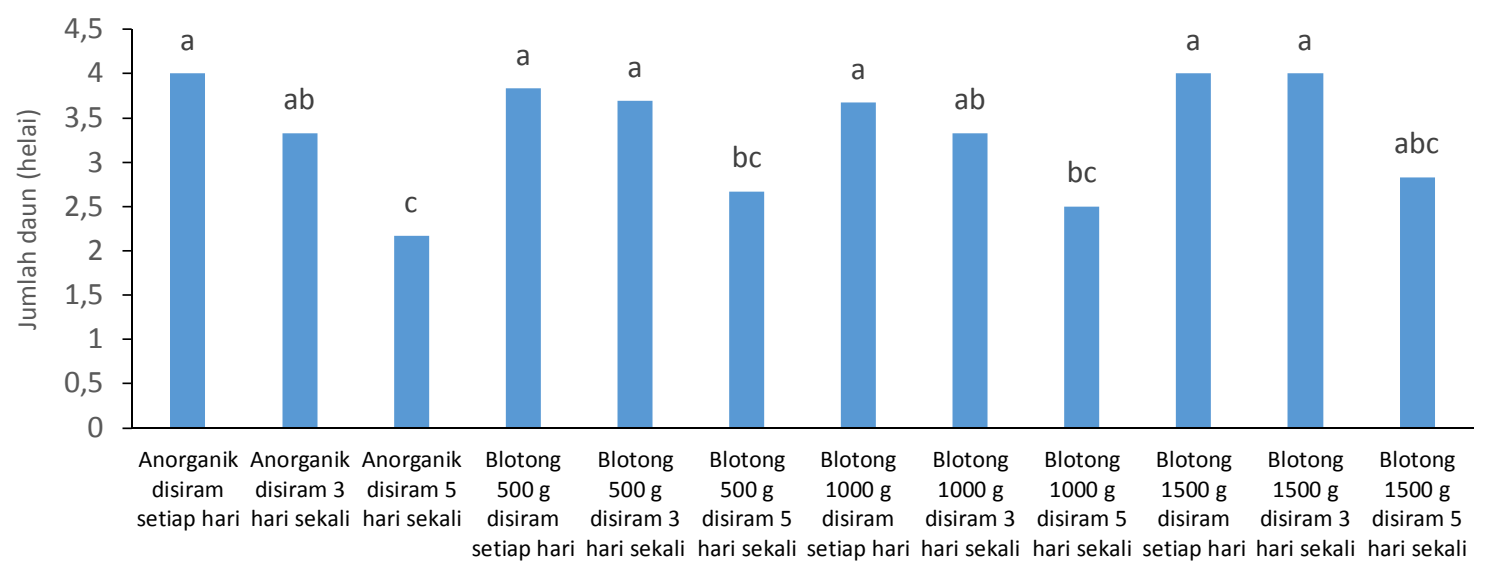

Gambar 2. Diagram rerata luas daun (a), rerata kandungan klorofil daun (b), rerata jumlah daun (c) bibit kelapa sawit dengan pemberian kompos blotong tebu dengan frekuensi penyiraman yang berbeda pada 4 BSP. 
Kelapa sawit biasanya menumbuhkan 1 daun setiap bulannya. Menurut Corley \& Tinker (2016) dan Verheye (2010), pada masa pembibitan rata-rata pertambahan jumlah daun kelapa sawit sebanyak satu helai/bulan sampai bibit kira-kira berumur enam bulan. Menurut Salisbury and Ross (1992), laju pembentukan daun (jumlah daun per satuan waktu) atau indeks plastokhron (selang waktu yang dibutuhkan per daun tambahan yang terbentuk) relatif konstan jika tanaman ditumbuhkan pada level suhu udara dan intensitas cahaya yang juga konstan.

Pemberian kompos blotong $1500 \mathrm{~g} /$ tanaman disertai penyiraman 3 hari sekali menghasilkan daun terluas dan berbeda nyata dengan pemberian pupuk anorganik disertai penyiraman 5 hari sekali, kompos blotong 500 $\mathrm{g} /$ tanaman disertai penyiraman 5 hari sekali, kompos blotong $1000 \mathrm{~g} /$ tanaman disertai penyiraman 3 hari sekali dan 5 hari sekali (Gambar 2a). Peningkatan luas daun dipengaruhi oleh unsur hara seperti N, P, dan K. Nitrogen berperan dalam pembentukan sel-sel baru, fosfor berperan mengaktifkan enzim-enzim dalam proses fotosintesis, dan kalium mampu mempengaruhi panjang dan lebar daun melalui peranannya dalam perkembangan jaringan meristem (Lakitan, 2010).

Perlakuan dengan pupuk anorganik, kompos $500 \mathrm{~g} /$ tanaman dan $1000 \mathrm{~g} /$ tanaman dengan penyiraman 5 hari sekali belum memberikan hasil pertumbuhan luas daun yang baik karena kandungan unsur hara dan air yang rendah. Hal ini didukung pernyataan Ai dan Banyo (2011) yang menyatakan bahwa defisit air pada tanaman akan mempengaruhi proses metabolisme di tingkat seluler dan molekuler, salah satunya ditandai dengan berkurangnya luas daun. Hal ini juga dibuktikan pada penelitian Asbur dan Ariyanti (2017), bahwa semakin tinggi curah hujan maka semakin meningkat luas daun.

Gambar 2b menunjukkan bahwa kandungan klorofil daun tidak dipengaruhi oleh pemupukan dan frekuensi penyiraman yang dilakukan. Kandungan klorofil daun bibit kelapa sawit umur 8 bulan berkisar antara 38 $53 \mathrm{mg} / \mathrm{cm}^{2}$ yang berarti bahwa setiap $1 \mathrm{~cm}^{2}$ luas daun terkandung 38-53 mg klorofil daun. Klorofil merupakan pigmen utama pada tanaman karena memiliki fungsi memanfaatkan energi matahari, memicu fiksasi $\mathrm{CO}_{2}$ untuk menghasilkan karbohidrat dan menyediakan energi dalam proses fotosintesis. Karbohidrat tersebut nantinya digunakan untuk membentuk protein, lemak, asam nukleat, dan molekul organik lainnya (Ai dan Banyo, 2011).

Pemberian kompos blotong dengan dosis tertinggi yaitu $1500 \mathrm{~g} /$ tanaman mampu menahan air dalam media tanam sehingga penyiraman 5 hari sekali masih mampu menghasilkan pertumbuhan jumlah daun yang tidak berbeda nyata dengan perlakuan penyiraman setiap hari dan 3 hari sekali (Gambar 2c). Selain itu perlakuan tersebut tidak berbeda nyata dengan perlakuan pemberian pupuk anorganik disertai penyiraman setiap hari. Ketersediaan air tanah dapat ditingkatkan dengan penambahan bahan organik, dimana bahan organik mampu meningkatkan ukuran pori dalam tanah sehingga daya pegang tanah akan air meningkat (Atmojo, 2003). Ketersediaan air dalam media tanam sangat penting mengingat bahwa kurangnya air bagi pertumbuhan kelapa sawit dapat menghambat pembentukan pelepah daun, klorosis, pelepah daun terkulai dan pupus patah (Mathius dkk., 2001).

Bobot basah menggambarkan keadaan segar tanaman dimana penimbangan dilakukan sesaat setelah tanaman dipisahkan dari media, jadi keadaan ini dapat dianggap sebagai keadaan tanaman pada saat masih ditanam dimana kegiatan metabolisme masih berjalan. Pemberian kompos blotong $1500 \mathrm{~g} /$ tanaman disertai penyiraman setiap hari menghasilkan bobot basah bibit kelapa sawit tertinggi dan berbeda nyata dengan dengan semua perlakuan pemupukan yang disertai penyiraman 5 hari sekali. Penyiraman 3 hari sekali pada berbagai level pemupukan masih menghasilkan bobot basah yang tidak berbeda nyata dengan penyiraman setiap hari sehingga frekuensi penyiraman ini masih memungkinkan keadaan turgor tanaman yang sama dengan penyiraman setiap hari. Penyiraman setiap hari merupakan kegiatan penyiraman yang umumnya dilakukan oleh praktisi kelapa sawit dengan asumsi bahwa kebutuhan air tanaman lebih terpenuhi dengan frekuensi penyiraman tersebut. Penghematan penggunaan air untuk penyiraman dapat dilakukan sampai dengan $60 \%$ untuk mempertahankan turgor bibit kelapa sawit terlebih apabila disertai dengan pemupukan organik secara optimal. Lestari dkk (2008) menyatakan bahwa bobot basah tanaman dapat menunjukkan aktivitas metabolisme tanaman dan nilai bobot basah tanaman dipengaruhi oleh 
kandungan air jaringan, unsur hara dan hasil metabolisme.

Humus dalam blotong juga ikut berperan dalam menunjang pertumbuhan tanaman meskipun tidak secara langsung. Humus biasanya bersifat porous sehingga humus mampu mengabsorpsi air dengan baik, sifat tersebut juga didukung oleh sifat kimia dari komponen humus yaitu selulosa dan hemiselulosa. Humus juga mempunyai kemam-puan yang tinggi dalam mengabsorpsi kation dan menukarkannya dengan garam-garam yang terdapat dalam larutan tanah, kation-kation yang dilepas ini merupakan sumber zat hara bagi tanaman (Satari dkk., 2009).

Bobot kering tanaman menggambarkan aktivitas tanaman mengakumulasikan produk dari proses fotosintesis dan merupakan integrasi dengan faktor-faktor lingkungan lainnya. Menurut Gardner et al. (1991), bobot kering total dan bahan suling tanaman budidaya di lapangan merupakan akibat dari penimbunan hasil bersih asimilasi $\mathrm{CO}_{2}$ sepanjang musim pertumbuhan. Produksi tanaman biasanya lebih akurat dinyatakan dengan ukuran bobot kering daripada dengan bobot basah, karena bobot basah sangat dipengaruhi oleh kondisi kelembaban. Proses fotosintesis menghasilkan fotosintat yang mempengaruhi proses pembentukan organ tanaman daun dan akar yang kemudian menghasilkan produksi bahan kering (Sitompul dan Guritno, 1995).

Bobot kering bibit kelapa sawit umur 8 bulan tampaknya belum dipengaruhi oleh faktor pemupukan dan frekuensi penyiraman (Gambar $3 b)$, meskipun demikian terdapat kecenderungan peningkatan bobot kering bibit kelapa sawit dengan pemberian kompos blotong 1500 $\mathrm{g} /$ tanaman disertai penyiraman setiap hari. Pada perlakuan berbagai level dosis pemberian kompos blotong, adanya pengurangan jumlah waktu penyiraman menyebabkan semakin rendahnya bobot kering bibit yang dihasilkan. Hal ini mengindikasikan bahwa bobot kering tanaman sebenarnya dipengaruhi oleh seberapa besar kebutuhan air terpenuhi bagi tanaman dimana terdapat kaitan dengan peranan kompos blotong sebagai penahan air pada media tanam. Pada level dosis kompos blotong 1500 $\mathrm{g} /$ tanaman, penurunan bobot kering tanaman tidak serendah dibandingkan pada level dosis kompos blotong $1000 \mathrm{~g} /$ tanaman dan 500 $\mathrm{g} /$ tanaman dikaitkan dengan frekuensi penyiraman yang diberikan. (a)

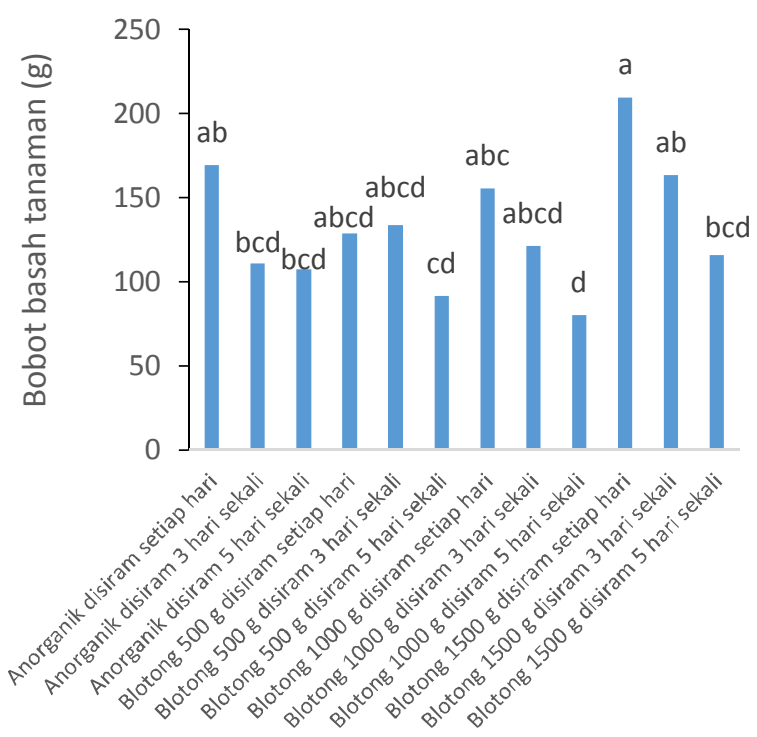

(b)

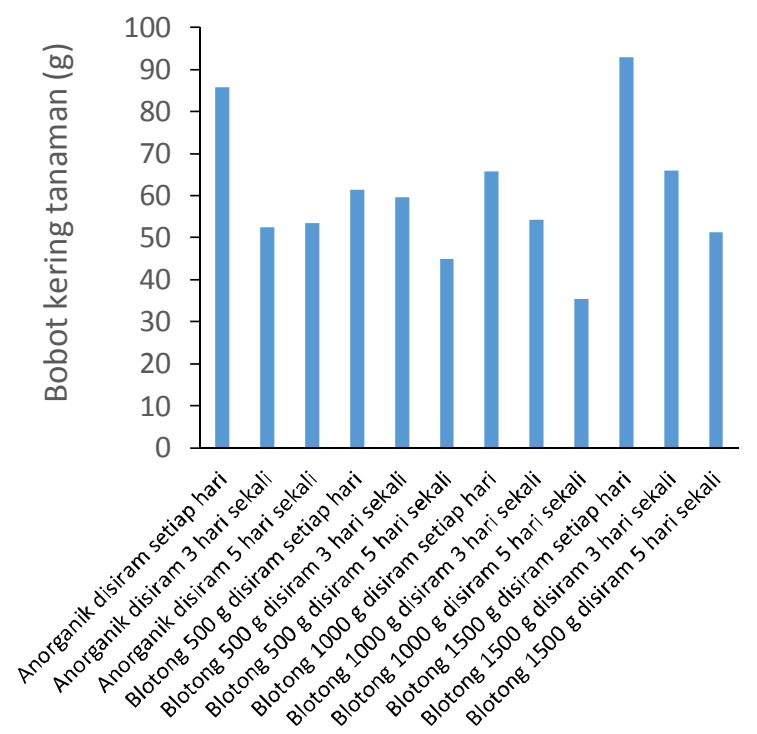

Gambar 3. Diagram rerata bobot basah (a) dan rerata bobot kering (b) bibit kelapa sawit dengan pemberian kompos blotong tebu dengan frekuensi penyiraman yang berbeda pada 4 BSP. 


\section{Kesimpulan}

1. Penggunaan kompos blotong sebagai pupuk organik disertai dengan frekuensi penyiraman yang optimal mempengaruhi pertumbuhan vegetatif bibit kelapa sawit di pembibitan utama terutama terhadap pertumbuhan tinggi tanaman, lilit batang, luas daun, jumlah daun dan bobot basah tanaman.

2. Pemberian kompos blotong dengan dosis kompos blotong $1500 \mathrm{~g} /$ tanaman disertai penyiraman setiap hari menghasilkan pertumbuhan terbaik bibit kelapa sawit terutama pengaruhnya terhadap parameter tinggi tanaman, lilit batang, jumlah daun dan bobot basah tanaman. Kompos blotong mengandung 32.38\% C-organik, $1.51 \% \mathrm{~N}$, $5.63 \% \mathrm{P}_{2} \mathrm{O}_{5}$, dan $0.26 \% \mathrm{~K}_{2} \mathrm{O}$.

\section{Daftar Pustaka}

Ai, N. S., Y. Banyo. 2011. Konsentrasi klorofil daun sebagai indikator kekurangan air pada tanaman. J. Ilmiah Sains (11) : 2 .

Allorerung, D., M. Syakir, Z. Poeloengan, Syafaruddin, dan W. Rumini. 2010. Budidaya Kelapa Sawit. Bogor: Aska Media, Pusat Penelitian dan Pengembangan Perkebunan.

Ariyanti, M., I.R.D. Anjarsari, Y. Maxiselly, Y.A. Chandra. 2018a. Pertumbuhan bibit kelapa sawit (Elaeis guineensis Jacq.) dengan komposisi media tanam dan interval penyiraman yang berbeda. J. Pen. Kelapa Sawit 26(1): 11-22. http:// jurnalkelapasawit.iopri.org/index.php/jp ks/article/view/58.

Ariyanti, M., S. Rosniawaty., I.R.D. Anjarsari., A. Fernando. 2018b. The growth response of oil palm seedling at main nursery against watering at different volume and frequency and against provision of compost. International Journal of Sciences: Basic and Applied Research. 37(3): 226233.http://gssrr.org/index.php?journal=J ournalOfBasicAndApplied\&page $=$ article \&op=view\&path $\% 5 B \% 5 D=8645$.

Asbur, Y. M. Ariyanti. 2017. Peran konservasi tanah terhadap cadangan karbon tanah, bahan organik, dan pertumbuhan kelapa sawit (Elaeis guineensis Jacq.). J. Kultivasi 16:(3).
Astuti, F., Y. Parapasan, and J.S.S. Hartono. 2015. Penggunaan kompos blotong dan pupuk nitrogen pada pembibitan kakao (Theobroma cacao L .). J. Agro Ind. Perkeb. 3(2): 122-134.

Atmojo, S. W. 2003. Peranan bahan organik terhadap kesuburan tanah dan upaya pengelolaannya. Pidato Pengukuhan Guru Besar Ilmu Kesuburan Tanah Fakultas Pertanian universitas Sebelas Maret.

Baskoro, D. P. T. 2017. Kelapa Sawit : Benarkah Rakus Air?. Buletin Faperta IPB. Tersedia dalam http://faperta.ipb.ac.id/buletin/ 2017/08/14/kelapa-sawit-benarkah-rakusair/. diakses pada tanggal 5 Agustus 2018.

Corley, R. H. V. dan P.B. Tinker. 2016. The Oil Palm (Fifth Edition). Oxford: Wiley Blackwell. Hlm. 1-149.

GAPKI (Gabungan Pengusaha Kelapa Sawit Indonesia). 2017. Perkebunan Kelapa Sawit : Hemat Air dan Lestraikan Cadangan Air Tanah. Tersedia pada https://gapki.id/ news/2027/ perkebunan-kelapa-sawithemat-air-dan-lestarikan-cadangan-airtanah. Diakses pada 5 Agustus 2018.

Gardner, F. P., R. Brent Pearce, Roger L. Mitchell. 1991. Fisiologi Tanaman Budidaya. Diterjemahkan oleh : Herawati Susilo. Penerbit. Universitas Indonesia. Jakarta.

Gunawan, E. Ariani, M. A. Khoiri. 2014. Pengaruh pemberian pupuk kandang ayam dan berbagai dosis pupuk urea terhadap pertumbuhan bibit kelapa sawit (Elaeis guineensis Jacq.) di main nursery. Jom Faperta (1) : 2 .

Ichsan, C.N., E. Nurami, and Saljuna. 2012. Respon aplikasi dosis kompos dan interval penyiraman pada pertumbuhan bibit kelapa sawit (Elaeis guineensis Jacq .). J. Agrista 16(2): 94-106.

Kirana, K. 2008. Penentuan dosis pemupukan kompos blotong pada tebu lahan kering (Saccharum officinarum L.) Varietas PS 862 dan PS 864. Skripsi Faperta IPB.

Lakitan, B. 2010. Dasar-Dasar Fisiologi Tumbuhan. Edisi 1. Rajawali Pers, Jakarta

Lestari, G.W, Solichatun, dan Sugiyarto. 2008. Pertumbuhan, kandungan klorofil, dan laju respirasi tanaman garut (Maranta arundinacea L.) setelah pemberian asam giberelat (GA3). Bioteknologi. 5(1):1-9.

Lubis, A.U. 2008. Kelapa Sawit (Elaeis guineensis Jacq.) di Indonesia (Edisi 2). Medan: Pusat Penelitian Kelapa Sawit. Hlm. 1-73 
Maryani, A.T. 2012. Pengaruh volume pemberian air terhadap pertumbuhan bibit kelapa sawit di pembibitan utama. J. Agroekoteknologi 1(2): 64-74.

Mathius, N.T., G. Wijaya, E. Guharja, H. Aswidinnoor, S. Yahya, and Subroto. 2001. Respons tanaman kelapa sawit (Elaeis guineensis Jacq.) terhadap cekaman kekeringan. Menara Perkeb. 69(2): 29-45.

Mulyadi, M. 2000. Kajian pemberian blotong dan terak baja pada tanah kandiudoxs pelaihari dalam upaya memperbaiki sifat kimia tanah, serapan $\mathrm{N}, \mathrm{Si}, \mathrm{P}$ dan $\mathrm{S}$ serta pertumbuhan tebu. Tesis. Program Pascasarjana, Institut Pertanian Bogor.

Pangaribuan, Y. 2001. Studi karakter morfofisiologi tanaman kelapa sawit (Elaeis guineensis Jacq.) di pembibitan terhadap cekaman kekeringan. Tesis. Program Pascasarjana. Institut Pertanian Bogor.

Purwono, D. Sopandie, S.S. Harjadi, and B. Mulyanto. 2011. Application of filter cake on growth of upland sugarcanes. J. Agron Indones. 39(2): 79-84.

Salisbury, F. B dan Ross, C. W. 1992. Fisiologi Tumbuhan Jilid 1 (Alihbahasa: Dian Rukmana dan Sumaryono). Bandung: ITB. Satari, G., T. Nurmala, O. A. A. Mihardja, A. W. Irwan, A. Wahyudin. 2009. Dasar - Dasar
Agronomi. Giratuna, Bandung.

Schmidt, F. H dan J. H. A. Ferguson. 1951. Rainfall Types Based On Wet and Dry Period Rations for Indonesia With Western New Guinea. Jakarta: Kementrian Perhubungan Meteorologi dan Geofisika

Sitompul S.M. dan Bambang Guritno. 1995. Analisis Pertumbuhan Tanaman. Gajah Mada University Press. Yogyakarta. Hal 113-114.

Verheye, W. 2010. Growth and Production of Oil Palm. In: Verheye, W. (ed.), Land Use, Land Cover and Soil Sciences. Encyclopedia of Life Support Systems (EOLSS), UNESCO-EOLSS Publishers, Oxford, UK. http://www.eolss.net.

World Growth. 2011. Manfaat Minyak Sawit bagi Perekonomian Indonesia. : 127Available at www.worldgrowth.org.

Yassen, A.A., S.. Khaled, and M.Z. Sahar. 2010. Response of wheat to different rates and rasios of organic residues on yield and chemical composition under two types of soil. J. Am. Sci. 6(12): 858-864.

Zaenal. 2010. Pengelolaan pembibitan kelapa sawit dengan aspek khusus seleksi bibit di pusat penelitian kelapa sawit (PPKS), Unit Usaha Marihat, Sumatera Utara. Skripsi Fak. Pertan. Inst. Pertan. Bogor. 